\title{
Effects of Water Depth, Cover and Food Resources on Habitat use of Marsh Birds and Waterfowl in Boreal Wetlands of Manitoba, Canada
}

Author(s) :Mark S. Baschuk, Nicola Koper, Dale A. Wrubleski and Gordon Goldsborough

Source: Waterbirds, 35(1):44-55. 2012.

Published By: The Waterbird Society

DOI: http://dx.doi.org/10.1675/063.035.0105

URL: http://www.bioone.org/doi/full/10.1675/063.035.0105

BioOne (www.bioone.org) is a nonprofit, online aggregation of core research in the biological, ecological, and environmental sciences. BioOne provides a sustainable online platform for over 170 journals and books published by nonprofit societies, associations, museums, institutions, and presses.

Your use of this PDF, the BioOne Web site, and all posted and associated content indicates your acceptance of BioOne's Terms of Use, available at www.bioone.org/ page/terms_of_use.

Usage of BioOne content is strictly limited to personal, educational, and noncommercial use. Commercial inquiries or rights and permissions requests should be directed to the individual publisher as copyright holder. 


\title{
Effects of Water Depth, Cover and Food Resources on Habitat Use of Marsh Birds and Waterfowl in Boreal Wetlands of Manitoba, Canada
}

\author{
Mark S. Baschuk ${ }^{1, *}$, Nicola Koper ${ }^{2}$, Dale A. Wrubleski ${ }^{3}$ and Gordon Goldsborough ${ }^{1}$ \\ ${ }^{1}$ Dept. of Biological Sciences, University of Manitoba, Winnipeg, Manitoba, R3T 2N2, Canada \\ ${ }^{2}$ Natural Resources Institute, University of Manitoba, Winnipeg, Manitoba, R3T 2N2, Canada \\ ${ }^{3}$ Ducks Unlimited Canada, P.O. Box 1160, Stonewall, Manitoba, R0C 2Z0, Canada \\ *Corresponding author; E-mail: mark.baschuk@gmail.com
}

\begin{abstract}
To evaluate water-level manipulations as a management tool in boreal wetlands, marsh bird and waterfowl habitat use were studied in the Saskatchewan River Delta, Manitoba, Canada, during 2008 and 2009. Call-response and aerial surveys were used to estimate densities of marsh birds and waterfowl, respectively, within six wetland basins undergoing two different water-level treatments. Generalized linear models were used to determine relationships between presence and densities of birds to water depth, vegetation characteristics, and relative forage fish and invertebrate abundances at two spatial scales. American Bittern (Botaurus lentiginosus) and Piedbilled Grebe (Podilymbus podiceps) densities were positively influenced by water depth and relative fish abundance. American Coots (Fulica americana) and diver waterfowl (Aythya, Bucephala) also responded positively to increased water depth, whereas dabbler waterfowl (Anas, Aix) were negatively influenced by increasing water depth. Densities of Sora (Porzana carolina) and Virginia Rail (Rallus limicola) were positively correlated with the relative abundances of invertebrates, but negatively correlated with relative fish abundance. Due to the high avian biodiversity in the region, managers should focus on providing a variety of wetland habitats. Using a combination of partial waterlevel drawdowns and high water, habitat for numerous avian species can be created simultaneously within wetland complexes. Received 23 March 2011, accepted 24 November 2011.
\end{abstract}

Key words.- - boreal wetlands, call-response, habitat use, marsh birds, waterfowl, water-level management.

Waterbirds 35(1): 44-55, 2012

Many marsh bird species including the American Bittern (Botaurus lentiginosus), American Coot (Fulica americana), Piedbilled Grebe (Podilymbus podiceps), Sora (Porzana carolina), Virginia Rail (Rallus limicola) and Yellow Rail (Coturnicops noveboracensis) found in the western boreal region of Canada are believed to be declining as a result of wetland loss (Eddleman et al. 1988; Conway et al. 1994; Timmermans et al. 2008). Due to the secretive nature of these species and lack of surveys, particularly in the boreal region, the extent of this decline is unknown. In addition to marsh birds, the western boreal region also provides important habitat for waterfowl, supporting approximately 14 million waterfowl every spring. (U.S. Fish and Wildlife Service Migratory Bird Data Center 2009). Management of this habitat is important for avian conservation, as wetland loss elsewhere in the prairie provinces has been severe; up to $71 \%$ of wetlands have disappeared in some areas as a result of anthropogenic developments (Natural Resources Canada 2009). Wetlands in the boreal are being impacted by agriculture, oil and gas development, forestry, hydro-electrical developments and mining (Prowse and Conly 2000; Timoney 2002; Timoney 2008; Partners FOR the Saskatchewan River Basin 2009).

The Saskatchewan River Delta remains an ecologically important boreal wetland ecosystem, despite having been strongly impacted by human activities. The delta spans $9,000 \mathrm{~km}^{2}$ across central Saskatchewan and Manitoba and is comprised of numerous wetlands, shallow lakes, and active and abandoned river channels separated from the Saskatchewan River by treed levees (Morozova and Smith 2003). One of the most prominent anthropogenic impacts in the delta has been the alteration of the water regime by upstream consumption and retention of water from the Saskatchewan River. Hydro-electric dams and water consumption for irrigation and petroleum production have reduced the water-flow peaks in the spring and summer (Partners FOR the Saskatchewan River Basin 2009). High water-flow peaks cause the Saskatchewan River to flood the wetlands 
that are separated from the river by natural levees. Periodic flooding is important for recharging delta wetlands and generating the dynamic state needed to keep these wetlands productive (Prowse and Conly 2000). However, unlike the prairies, effects of common management practices, such as water-level manipulations on avian productivity, are not well understood, and require quantitative assessments to facilitate effective management.

Variations in water depth influence the species composition and abundance of emergent and submersed vegetation in wetlands (Robel 1961; Anderson 1978; Seabloom et al. 1998; van der Valk 2000). The vegetation, in turn, influences the amount of available food, nesting and thermal cover for marsh birds and waterfowl (Robel 1961; Murkin et al. 1997). Also, water depth affects available food resources because it limits access by some avian species (Baker 1979; Poysa 1983a). Water depth can also influence invertebrate populations, which provide an important food source for waterfowl (Murkin and Kadlec 1986; Cox et al. 1998) and for several species of marsh birds, including Sora, Virginia Rail and Pied-billed Grebe (Horak 1970; Krull 1970; Rundle and Sayre 1983; Muller and Storer 1999; Longcore et al. 2006).

The abundance and diversity of forage fish is also influenced by water depth (Sargent and Galat 2002). Not only do forage fish provide food for several marsh bird species, including American Bittern and Piedbilled Grebe (Brisbin and Mowbray 2002; Lowther et al. 2009), forage fish can impact habitat use by insectivorous avian species by directly competing against birds for invertebrates (Bouffard and Hanson 1997; Zimmer et al. 2000; Hornung and Foote 2006).

Because water depth plays such an important role in determining the quality and quantity of habitat for marsh birds, we evaluated effects of wetland water-level manipulations on marsh birds in the Saskatchewan River Delta at two different spatial scales. The objectives of our study were to: (1) identify the species and density estimates of marsh birds and waterfowl present in the Summerberry Marsh Complex of the Saskatchewan River
Delta, a major boreal wetland ecosystem, and (2) evaluate the effects of two water-level treatments, a partial water-level drawdown and high water, in this system on marsh birds and waterfowl during the breeding season.

Methods

\section{Study Area}

Field work for this study was performed in 2008 and 2009 in the Summerberry Marsh Complex (SMC), in the Saskatchewan River Delta, approximately $25 \mathrm{~km}$ southeast of The Pas, Manitoba (Fig. 1). The SMC covers approximately 15,000 ha, primarily between the Summerberry and Saskatchewan Rivers, consisting of a series of permanent marshes and shallow lakes formed by the two bordering rivers. Ducks Unlimited Canada manages water levels in the complex using 28 watercontrol structures on individual wetland basins.

Six wetlands in the SMC, ranging in size from 84207 ha, were selected for the experimental design (Fig. 2 ). Each wetland basin is equipped with a water-control structure that opens into the Saskatchewan River or connecting channel, allowing water levels to be controlled by releasing water from the wetland via gravity flow or capturing water from the river or connecting channel during high-water periods or by the retention of precipitation. Emergent vegetation within the wetlands is typically a mixture of Sedge (Carex spp.) and Horsetail (Equisetum spp.) along the shallower periphery of the wetlands. In the deeper, more central parts of the wetlands, vegetation is a mix of Giant Reed Grass (Phragmites australis), Cattail (Typha spp.) Hardstem Bulrush (Schoenoplectus tabernaemontani) and Burreed (Sparganium spp.).

Three of the wetlands were partially drawn down to emulate natural drawdown conditions. Water levels were lowered to approximately $60 \mathrm{~cm}$ in the deepest part of the basins, with an average water depth of 30 $\mathrm{cm}(\mathrm{SD}=19 \mathrm{~cm})$, which did not expose mudflats. The

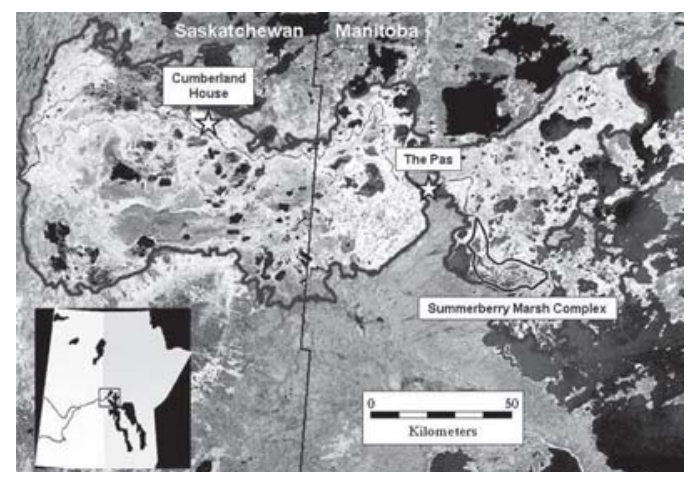

Figure 1. Location and extent of the Saskatchewan River Delta in Saskatchewan and Manitoba, Canada, and the Summerberry Marsh Complex. 


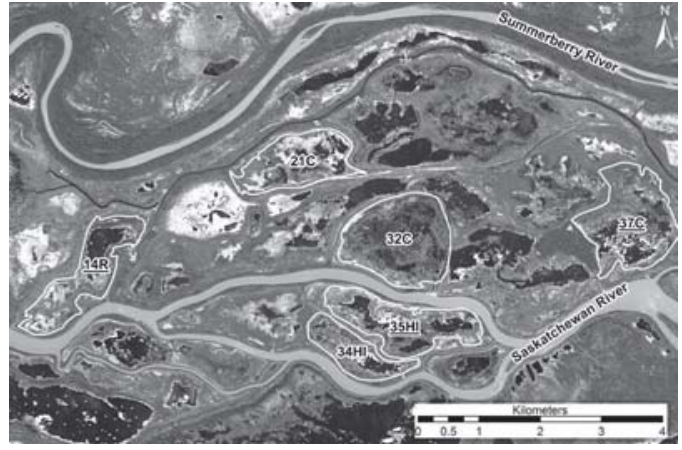

Figure 2. Study wetlands outlined by their Full Supply Level within the Summerberry Marsh Complex, Manitoba, Canada. The names of the three partially drawn down wetlands are labeled with an underline.

partial water-level drawdowns were initiated on $10 \mathrm{Au}-$ gust 2007 and were completed by September 2007; water levels were maintained at target levels through 2010 although our data reported here were collected in 2008 and 2009, mid-way through the drawdown period. The remaining three wetlands were managed to maintain their high water levels. The water levels in these basins remained at approximately $100 \mathrm{~cm}$ in the deepest part of the basins, with an average depth of $67 \mathrm{~cm}$ (SD $=24$ $\mathrm{cm})$. Water levels in the high-water basins have been held relatively constant since 2005 .

\section{Marsh Bird and Waterfowl Surveys}

Call-response surveys for marsh birds were performed at 35 points in 2008 ( $n=17$ in the partial drawdown wetlands and $n=18$ in the high-water wetlands) and 40 points in 2009 ( $n=21$ in the partial drawdown wetlands and $n=19$ in the high-water wetlands). Survey points were spaced a minimum distance of $400 \mathrm{~m}$ apart. Surveys were conducted from a canoe, with the exception of the points along the upland/wetland interface. Surveys began a half-hour before sunrise, and lasted no later than 10:00 h. A portable audio system and MP3 player were used to broadcast territorial calls of the target species at a volume of 80-90 db measured $1 \mathrm{~m}$ from the speakers (Conway 2005).

The broadcast sequence consisted of five minutes of silence/passive listening followed by 30 seconds of call from one species and 30 seconds of silence, then $30 \mathrm{sec}-$ onds of call of another species and 30 seconds of silence, repeated until all species' calls had been broadcast. In 2008, the broadcast sequence consisted of territorial calls of the target species in the following order: Least Bittern (Ixobrychus exilis), Yellow Rail, Sora, Virginia Rail, American Bittern and Pied-billed Grebe. In 2009, the broadcast sequence was changed to: Sora, Virginia Rail, American Bittern, American Coot and Pied-billed Grebe. The Least Bittern and Yellow Rail were dropped from the call-response sequence in 2009 due to a lack of detections in 2008. In 2008 one observer recorded bird vocalizations and in 2009 vocalizations were recorded using a double-observer approach (Nichols et al. 2000).
In 2009, two observers sat at opposite ends of the canoe during surveys and independently recorded data.

Surveys were conducted four times in each study wetland at ten-day intervals from 27 May-2 July 2008 and four times in each study wetland from 15 May-25 June 2009. Each wetland took one day to survey. Surveys were not conducted during rain or if wind speed exceeded $20 \mathrm{~km} / \mathrm{h}$. Densities of marsh birds were compared between the partial drawdown and high-water wetlands using an unpaired $t$-test.

In 2009, waterfowl spring-breeding surveys were conducted using a helicopter. Surveys were flown at a height of $30 \mathrm{~m}$, with a speed of $50 \mathrm{~km} / \mathrm{h}$. The helicopter travelled along the periphery of the open water/emergent vegetation interface of each of the six study wetlands to allow two observers, sitting on the same side of the aircraft, one in the front seat and one in the back seat, to overlook the wetland. Two dependent observers, using voice recorders, counted and recorded all visible waterfowl out to a distance of no more than $250 \mathrm{~m}$, which were identified to species and flock arrangement. The primary observer recorded all birds that he detected and indicated these, via the radio system, to the secondary observer. The secondary observer recorded any birds that were not detected by the primary observer. The primary and secondary observer roles were chosen randomly and switched at mid-point during the survey. A single pass around the wetland was done and an additional pass over the center of some of the larger, more circular wetlands was required to ensure complete coverage. Surveys began at approximately 08:00 $\mathrm{h}$, and were conducted twice: 22 May and 10 June 2009. The surveys were not conducted during rain or if wind speed exceeded 20 $\mathrm{km} / \mathrm{h}$. Densities of dabbler and diver waterfowl were compared between the partial drawdown and highwater wetlands using an unpaired $t$-test.

\section{Invertebrate Sampling}

In 2009, activity traps and sticky traps were used to sample nektonic and flying invertebrates, respectively. Activity traps followed the design of Riley and Bookhout (1990) and were set in pairs, one mounted horizontally and the other mounted vertically from a "t" frame made of wood that was driven into the substratum. Traps were set $30 \mathrm{~cm}$ below the surface of the water. Samples from the activity traps were filtered through a $1 \mathrm{~mm}$ size sieve and remaining invertebrates were counted to determine relative abundance. Species of invertebrates were not identified and all invertebrates were assumed to be equally available to marsh birds and waterfowl.

Sticky traps followed the design of King and Wrubleski (1998). A cylinder, $6.25 \mathrm{~cm}$ in diameter, and $25 \mathrm{~cm}$ long, was wrapped with a transparent, plastic sheet that was coated with Tanglefoot (The Tanglefoot Co., Grand Rapids, MI). The cylinder was placed on the top of the " $\mathrm{t}$ " frame that held the activity traps, immediately above the surface of the water. After the sampling period, the plastic sheets were removed and the invertebrates caught on the sheet were counted. 
Two "t" frames holding a horizontal and vertical activity trap, and sticky trap, were deployed at random open water areas of the wetlands ( $>3 \mathrm{~m}$ from emergent vegetation) within a $200-\mathrm{m}$ radius of each call-response point for 24 hours. Traps were not deployed within emergent vegetation in order to minimize disturbance to emergent vegetation. Sampling was done concurrently in one partial-drawdown and one high-water wetland from 15 May-25 June 2009. Each wetland was sampled four times during this period.

\section{Forage Fish Sampling}

In 2008 and 2009 a fish trap following the design of Beamish (1973) was used to sample small fish (hereafter, "forage fish") that may have been available for depredation by piscivorous birds. American Bitterns and Piedbilled Grebes include small fish in their diet, including Stickleback (Gasterostidae) (Muller and Storer 1999; Lowther et al. 2009). Five Northern Pike (Esox lucius) were captured in 2009 but were excluded from our analyses because we considered them too large $(25-49 \mathrm{~cm})$ to be potential prey items. We assumed that all remaining fish were available as prey, but acknowledge that the size range of fish we surveyed may not have corresponded exactly with the size of fish consumed by birds.

The fish traps were constructed of $1.5 \mathrm{~mm}$ mesh, with 3-m long wings that funneled fish through a 15 $\times 15 \mathrm{~cm}$ square opening into a compartment. In late August 2008, two drawdown wetlands and two highwater wetlands were sampled using two traps set for 24 hours. One drawdown wetland and one high-water wetland were not sampled in 2008. Data for 2008 were substituted for these wetlands with data from 2009 as the numbers of fish caught did not significantly differ between 2008 and 2009 in the other wetlands, according to a paired $t$-test $(p=0.19)$. In 2009, sampling was conducted in late August through September. Each wetland was sampled using two traps set for two 24-hour periods. In both years, captured fish were identified to species [Brook Stickleback (Culaea inconstans), Central Mudminnow (Umbra limi) and Fathead Minnow (Pimephales promelas)], counted, and released back into the wetland. Relative fish abundance was estimated using the index of number of fish caught per trap hour.

\section{Emergent Vegetation Mapping}

Emergent vegetation maps were created for each study wetland for 2008 and 2009. These maps were created from 0.6-m resolution QuickBird satellite imagery containing four bands: red, green, blue, and near infrared taken on 4 July 2008 and 7 July 2009. Definiens Developer $7 \circledR$ software was used to segment the imagery into polygons and ground truthing was performed in 2009 at 400-600 points within each of the study wetlands to identify the dominant vegetation species and create a reference set of polygons representing the different vegetation classes. Generalized logistic models were then used to classify vegetation types within the polygons based on their spectral characteristics (Baschuk 2010). Cover types identified by these maps included
Burreed (Sparganium spp.), Sedge (Carex spp.), Horsetail (Equisetum spp.), Hardstem Bulrush (Schoenoplectus tabernaemontani), Cattail (Typha spp.), Giant Reed Grass (Phragmites australis), open water, and trees [dominated by Willows (Salix spp.) but also included Poplar (Populus spp.), Manitoba Maple (Acer negundo), Green Ash (Fraxinus pennsylvannica) and other species].

From these maps the proportions of shallow-marsh vegetation (Sedge and Horsetail) and deep-marsh vegetation (Burreed, Bulrush, Cattail, Giant Reed Grass) were determined for 2008 and 2009 by totaling the areas of these respective classes and dividing it by the wetland's boundary defined by the Full Supply Level (FSL). The FSL is the highest elevation Ducks Unlimited Canada manages the water levels, and consequently is where the tree line begins (Fig. 2). Vegetation edge density (vegetation interspersion) was also calculated from these maps by determining the lengths of vegetationwater interface and dividing it by the wetland's FSL.

During ground truthing we used a metre stick attached to a 2" $\times 2$ " piece of lumber to measure water depth at 400-600 points in each of our study wetlands. Depth measurements made in the open-water areas of the wetlands ( $>3 \mathrm{~m}$ away from emergent vegetation) were used to calculate average open-water depth and provide a measure of the treatment for the wetlandscale analysis. Because waterbird surveys were usually conducted from a vegetated wetland edge and included both open water and habitat dominated by emergent vegetation, depth measurements made within a 200-m radius of our call-response points used measurements from both open water and vegetated areas to calculate the average water depth for our plot-scale analysis.

\section{Data Analysis}

\section{Observer Detection Probability}

Prior to data analysis, observer detection probabilities were calculated for the 2009 marsh bird and waterfowl survey data to determine if the observed number of birds required adjustment due to observer bias. The program DOBSERV (Hines 2000) was used to estimate detection probabilities for each species. In order to obtain a more accurate estimation of detection probability analysis of the marsh bird data used detections from all four surveys, and included detections from individual birds that were detected at multiple points during a survey. To determine if both observers detected the same bird, the species, distance, time of first detection, and call type were compared from the recorded data of the two observers. Since the independent observer method was used, the primary and secondary observer roles were determined a posteriori by randomly choosing a primary observer for the first point and alternating roles at subsequent points. Analysis of the waterfowl data used detections from both surveys.

Wetland Scale Habitat Use Models. To examine the effects of the water-level treatments and other habitat characteristics on the settling patterns of marsh birds and waterfowl, habitat use models were constructed at the wetland scale. 
Waterfowl were grouped into dabbler (Anas, Aix) and diver (Aythya, Bucephala) categories prior to analysis. The total number of marsh birds detected during the first two call-response surveys and the total number of dabblers and divers from both aerial surveys were divided by the wetland's area to calculate the density of each species per unit wetland area. Only the number of marsh birds from the first two call-response surveys were used as this was the peak of the breeding season, when marsh birds were most likely to be detected. The total number of birds counted was used in the analyses rather than averages to allow the use of distributions representing count data in the modeling procedure. The GENMOD procedure in SAS 9.2 was used to model the density (birds $/ \mathrm{km}^{2}$ ) of each species in 2008 and 2009. The two years were analyzed separately to allow for a comparison between years. Models were not created for Yellow Rails or Least Bitterns due to an insufficient number of detections. Models were fit using either the negative binomial or Poisson distribution, with a log-link function. Importance of independent variables in the models was assessed using hypothesis testing with an $\alpha=0.1$. If models were overdispersed (Pearson's chi-square/df $>1.67$ ) or underdispersed (Pearson's chi-square/df $<0.95$ ), the covariance matrix was multiplied by the Pearson's chi-square/df value to account for the dispersion. Due to the small number of wetlands in the study, the degrees of freedom available for the analyses were small. Therefore, univariate models were analyzed. The models used in the analyses were: average open-water depth, vegetation edge density as a measure of vegetation interspersion, proportion of shallow-marsh vegetation (Sedge and Horsetail), proportion of deep-marsh vegetation (Burreed, Bulrush, Cattail, Giant Reed Grass), number of forage fish caught per trap hour, number of invertebrates caught in the activity traps during the first two survey rounds, and the number of invertebrates caught on the sticky traps during the first two survey rounds.

Plot Scale Habitat Use Models. To examine the effects of water-level treatments and other habitat characteristics on microhabitat selection and territory establishment of marsh birds, statistical models were constructed using plot-scale habitat variables. Plot-scale models could not be constructed for waterfowl as waterfowl surveys were only conducted at the wetland scale.

Plots were designated as a $200-\mathrm{m}$ radius, circular buffer around each call-response point. Emergent vegetation characteristics were measured within these 200-m radius plots. The GLIMMIX procedure in SAS 9.2 was used to model the presence or absence of the marsh birds in 2008 and 2009 from the first two survey rounds. The two years were analyzed separately to allow for a comparison between years. Only initial detections of marsh birds within $200 \mathrm{~m}$ of the point were used; repeat detections and detections further than $200 \mathrm{~m}$ were eliminated from the analyses. We included "Wetland" as a random variable to account for possible variation in plots among wetlands. Models were fit using a binomial distribution and a log-link function. Importance of independent variables in the models were assessed using hypothesis testing with an $\alpha=0.1$. Due to the relatively small number of plots in the study, the degrees of freedom available for the analyses were small and univariate models were analyzed. The models used in the analyses were: average water depth, vegetation edge density as a measure of vegetation interspersion, proportion of shallow-marsh vegetation (Sedge and Horsetail), proportion of deep-marsh vegetation (Burreed, Bulrush, Cattail, Giant Reed Grass) and the number of invertebrates caught in the activity traps and sticky traps during the first two survey rounds.

\section{RESULTS}

Detection probabilities of marsh birds and waterfowl were high (Table 1). Marsh bird detection probabilities ranged from 0.92 to 0.95 . Blue-winged Teal, Mallard and Ring-necked Duck, which made up a majority of the waterfowl observed, had detection probabilities ranging from 0.98 to 1.0. As a result of the high detection probabilities, we used the observed number of birds for analyses rather than the estimated number created by the DOBSERV models.

We did not detect any Least Bitterns and only one Yellow Rail during the first two callresponse surveys in 2008. Densities of American Bitterns, Pied-billed Grebes and American Coots were significantly higher in the highwater wetlands compared to the drawdown wetlands in both 2008 and $2009(p=0.02)$.

Table 1. Detection probabilities and estimated number of individuals (n) of marsh bird and waterfowl species observed during call-response surveys in 2009 in the Summerberry Marsh Complex, Manitoba.

\begin{tabular}{lrcrc}
\hline Species & N & $\begin{array}{c}\text { Detection } \\
\text { Probability }\end{array}$ & $\mathrm{n}$ & $\begin{array}{c}\text { SE } \\
(\mathrm{n})\end{array}$ \\
\hline American Bittern & 32 & 0.92 & 35 & 2.29 \\
American Coot & 66 & 0.92 & 72 & 3.32 \\
Pied-billed Grebe & 118 & 0.94 & 125 & 3.45 \\
Sora & 128 & 0.95 & 134 & 3.14 \\
Virginia Rail & 61 & 0.93 & 66 & 3.01 \\
American Wigeon & 9 & 0.97 & 9 & 0.63 \\
Blue-winged Teal & 173 & 0.99 & 175 & 1.66 \\
Bufflehead & 7 & 0.97 & 7 & 0.54 \\
Canvasback & 27 & 0.92 & 29 & 2.91 \\
Gadwall & 1 & 0.97 & 1 & 0.19 \\
Green-winged Teal & 9 & 0.97 & 9 & 0.63 \\
Mallard & 134 & 0.98 & 137 & 2.52 \\
Northern Pintail & 2 & 0.97 & 2 & 0.27 \\
Northern Shoveler & 8 & 0.97 & 8 & 0.59 \\
Redhead & 1 & 0.97 & 1 & 0.19 \\
Ring-necked Duck & 261 & 1.00 & 262 & 1.12 \\
Scaup & 14 & 1.00 & 14 & NA \\
\hline
\end{tabular}


Densities of Soras and Virginia Rails did not significantly differ between the two water-level treatments $(p=0.76)$ (Table 2$)$. Dabbler species of waterfowl had higher densities in the drawdown wetlands, but not significantly so $(p$ $=0.37$ ). Diver waterfowl had higher densities in the high-water wetlands, but was not found to be significantly different from the partial drawdown wetlands $(p=0.08)$ (Table 2).

\section{Wetland Scale Habitat Use Models}

American Bittern, American Coot and Pied-billed Grebe densities were positively related to water depth (Table 3). The water depth relationship was strongest for American Bitterns and Pied-billed Grebes in 2009, at which point the model predicted that a 10 $\mathrm{cm}$ increase in water depth would result in an approximate $0.15 \mathrm{bird} / \mathrm{km}^{2}$ increase of American Bittern and Pied-billed Grebe densities during a single survey round. Sora and Virginia Rail densities did not appear to be affected by water depth. Dabbler and diver waterfowl densities showed opposite relationships to water levels. Dabblers responded negatively to water depth, whereas divers responded positively. The models predicted a $10 \mathrm{~cm}$ increase in water depth would decrease dabbler density by $0.10 \mathrm{bird} / \mathrm{km}^{2}$ and increase diver density by $0.10 \mathrm{bird} / \mathrm{km}^{2}$ during a single survey (Table 4 ).

Vegetation edge densities only affected Pied-billed Grebe density in 2008, indicating an approximate $2.0 \mathrm{bird} / \mathrm{km}^{2}$ increase per $\mathrm{km} /$ ha increase in vegetation edge density, or interspersion (Table 3). Dabblers showed a negative relationship with vegetation interspersion showing a decrease of $2.7 \mathrm{bird} /$ $\mathrm{km}^{2}$, whereas divers showed an increase of approximately $2.0 \mathrm{bird} / \mathrm{km}^{2}$ per $\mathrm{km} /$ ha increase in vegetation interspersion (Table 4).

The proportion of shallow-marsh and deep-marsh vegetation had opposing effects on the densities of Sora, Virginia Rail, and dabbler species of waterfowl in 2009. For these species, increasing proportion of shallow-marsh vegetation increased their densities, whereas increasing proportion of deep-marsh vegetation tended to decrease their densities. In contrast, the proportion of deep-marsh vegetation had a positive effect on Pied-billed Grebe densities in 2008.

Densities of piscivorous birds, including American Bitterns and Pied-billed Grebes, tended to be positively correlated with relative abundance of forage fish in 2009 (Table $3)$. In contrast, Sora and dabbler waterfowl densities were negatively correlated with the relative abundance of forage fish, but Sora densities increased in areas with high nektonic and relative flying invertebrate abundance. Virginia Rail densities were also greater within wetlands supporting higher relative abundances of flying invertebrates.

\section{Plot Scale Habitat Use Models}

American Bittern, American Coot and Pied-billed Grebe presence were all positively related to increasing water depth. Sora and Virginia Rail presence did not appear to be affected by water depth at this scale. The relationship to water depth was strongest for Pied-billed Grebes; probability of occurrence increased by 0.4 with a $10 \mathrm{~cm}$ increase in water depth (Table 5).

American Bittern, American Coot and Pied-billed Grebe presence were also

Table 2. Densities of marsh birds and waterfowl (birds $\left./ \mathbf{k m}^{2}\right)$ in the partial drawdown and high-water wetlands of the Summerberry Marsh Complex, Manitoba in 2008 and 2009. Results are not (not available) for American Coots or waterfowl in 2008 as they were not surveyed.

\begin{tabular}{|c|c|c|c|c|}
\hline & \multicolumn{2}{|c|}{2008} & \multicolumn{2}{|c|}{2009} \\
\hline & Drawdown & High Water & Drawdown & High Water \\
\hline American Bittern & 6 & 9 & 1 & 4 \\
\hline Pied-billed Grebe & 7 & 17 & 2 & 13 \\
\hline Sora & 7 & 12 & 10 & 8 \\
\hline Virginia Rail & 2 & 4 & 3 & 3 \\
\hline American Coot & NA & NA & 2 & 9 \\
\hline Dabbler Waterfowl & NA & NA & 52 & 27 \\
\hline Diver Waterfowl & NA & NA & 21 & 48 \\
\hline
\end{tabular}


Table 3. Wetland-scale effects of resource availability on densities of marsh birds in the Summerberry Marsh Complex, Manitoba in 2008 and 2009. Results are not available (NA) for invertebrate variables and the American Coot in $\mathbf{2 0 0 8}$ as these were not sampled. Response estimates are for bird densities over two survey rounds.

\begin{tabular}{|c|c|c|c|c|c|c|}
\hline & \multicolumn{3}{|c|}{2008} & \multicolumn{3}{|c|}{2009} \\
\hline & Estimate & SE & $p$ & Estimate & SE & $\mathrm{p}$ \\
\hline \multicolumn{7}{|l|}{ American Bittern } \\
\hline Avg. Open Water depth $(\mathrm{cm})$ & 0.01 & 0.01 & 0.06 & 0.05 & 0.02 & 0.01 \\
\hline Vegetation Edge density $(\mathrm{km} / \mathrm{ha})$ & 2.21 & 1.41 & 0.12 & -6.84 & 5.11 & 0.18 \\
\hline Proportion shallow-marsh vegetation & 1.24 & 0.98 & 0.21 & -4.37 & 3.24 & 0.18 \\
\hline Proportion deep-marsh vegetation & 0.47 & 0.64 & 0.47 & 3.20 & 2.65 & 0.23 \\
\hline Fish per trap hour & 0.02 & 0.01 & 0.13 & 0.06 & 0.02 & 0.00 \\
\hline Invertebrates sticky trap & NA & NA & NA & 0.00 & 0.07 & 0.96 \\
\hline Invertebrates activity trap & NA & NA & NA & -0.07 & 0.08 & 0.38 \\
\hline \multicolumn{7}{|l|}{ American Coot } \\
\hline Avg. Open Water depth $(\mathrm{cm})$ & NA & NA & NA & 0.03 & 0.02 & 0.08 \\
\hline Vegetation Edge density $(\mathrm{km} / \mathrm{ha})$ & NA & NA & NA & 0.89 & 6.27 & 0.89 \\
\hline Proportion shallow-marsh vegetation & NA & NA & NA & 1.35 & 3.65 & 0.71 \\
\hline Proportion deep-marsh vegetation & NA & NA & NA & -1.49 & 2.71 & 0.58 \\
\hline Fish per trap hour & NA & NA & NA & 0.05 & 0.05 & 0.32 \\
\hline Invertebrates sticky trap & NA & NA & NA & 0.10 & 0.08 & 0.21 \\
\hline Invertebrates activity trap & NA & NA & NA & 0.05 & 0.07 & 0.50 \\
\hline \multicolumn{7}{|l|}{ Pied-billed Grebe } \\
\hline Avg. Open Water depth (cm) & 0.02 & 0.01 & 0.00 & 0.04 & 0.01 & 0.01 \\
\hline Vegetation Edge density $(\mathrm{km} / \mathrm{ha})$ & 3.84 & 1.59 & 0.02 & -1.59 & 5.99 & 0.79 \\
\hline Proportion shallow-marsh vegetation & -0.02 & 1.58 & 0.99 & -0.94 & 3.25 & 0.77 \\
\hline Proportion deep-marsh vegetation & 1.79 & 0.83 & 0.03 & 0.42 & 2.40 & 0.86 \\
\hline Fish per trap hour & 0.03 & 0.02 & 0.12 & 0.06 & 0.03 & 0.04 \\
\hline Invertebrates sticky trap & NA & NA & NA & 0.06 & 0.06 & 0.34 \\
\hline Invertebrates activity trap & NA & NA & NA & 0.01 & 0.06 & 0.88 \\
\hline \multicolumn{7}{|l|}{ Sora } \\
\hline Avg. Open Water depth $(\mathrm{cm})$ & 0.01 & 0.01 & 0.25 & -0.01 & 0.01 & 0.18 \\
\hline Vegetation Edge density $(\mathrm{km} / \mathrm{ha})$ & 0.69 & 2.90 & 0.81 & 0.61 & 2.23 & 0.78 \\
\hline Proportion shallow-marsh vegetation & 1.47 & 1.52 & 0.33 & 3.18 & 1.19 & 0.01 \\
\hline Proportion deep-marsh vegetation & 1.07 & 0.95 & 0.26 & -2.79 & 0.78 & 0.00 \\
\hline Fish per trap hour & -0.03 & 0.03 & 0.29 & -0.04 & 0.02 & 0.09 \\
\hline Invertebrates sticky trap & NA & NA & NA & 0.04 & 0.02 & 0.02 \\
\hline Invertebrates activity trap & NA & NA & NA & 0.06 & 0.03 & 0.08 \\
\hline \multicolumn{7}{|l|}{ Virginia Rail } \\
\hline Avg. Open Water depth $(\mathrm{cm})$ & 0.01 & 0.02 & 0.45 & -0.02 & 0.02 & 0.46 \\
\hline Vegetation Edge density $(\mathrm{km} / \mathrm{ha})$ & 0.24 & 4.07 & 0.95 & 0.42 & 4.19 & 0.92 \\
\hline Proportion shallow-marsh vegetation & 0.21 & 2.06 & 0.92 & 6.48 & 2.32 & 0.01 \\
\hline Proportion deep-marsh vegetation & 0.18 & 1.26 & 0.89 & -5.49 & 1.51 & 0.00 \\
\hline Fish per trap hour & -0.09 & 0.06 & 0.16 & -0.03 & 0.04 & 0.51 \\
\hline Invertebrates sticky trap & NA & NA & NA & 0.09 & 0.03 & 0.00 \\
\hline Invertebrates activity trap & NA & NA & NA & 0.09 & 0.06 & 0.15 \\
\hline
\end{tabular}

positively related to edge density, or interspersion. Again, this relationship was strongest for Pied-billed Grebes. The probability of occurrence of Pied-billed Grebes increased by approximately 3.0 for every $\mathrm{km} / \mathrm{ha}$ increase of interspersion (Table 5).

The only species to show a relationship to vegetation at this scale was Virginia Rail, which was negatively related to the proportion of deep-marsh vegetation in 2009. Virginia Rails were also positively related to the relative abundance of nektonic invertebrates.

\section{Discussion}

Although water depth did influence habitat selection by marsh birds and waterfowl, effect sizes estimated from our models were small. These low effect sizes may be due to a non-linear relationship with water depth (Bolduc and Afton 2008), which we could not explore due to our low sample sizes. Nonetheless, our results are consistent with previous literature that demonstrates the importance of water depth to marsh birds and waterfowl. 
Table 4. Wetland-scale effects of resource availability on densities of waterfowl in the Summerberry Marsh Complex, Manitoba in 2008 and 2009. Response estimates are for bird densities over two survey rounds.

\begin{tabular}{|c|c|c|c|}
\hline & \multicolumn{3}{|c|}{2009} \\
\hline & Estimate & $\mathrm{SE}$ & $\mathrm{p}$ \\
\hline \multicolumn{4}{|l|}{ Dabbler Species } \\
\hline Avg. Open Water depth $(\mathrm{cm})$ & -0.02 & 0.01 & 0.02 \\
\hline Vegetation Edge density $(\mathrm{km} / \mathrm{ha})$ & -5.43 & 2.20 & 0.01 \\
\hline Proportion shallow-marsh vegetation & 3.39 & 1.61 & 0.04 \\
\hline Proportion deep-marsh vegetation & -2.88 & 1.34 & 0.03 \\
\hline Fish per trap hour & -0.06 & 0.03 & 0.02 \\
\hline Invertebrates sticky trap & 0.02 & 0.02 & 0.14 \\
\hline Invertebrates activity trap & 0.03 & 0.06 & 0.58 \\
\hline \multicolumn{4}{|l|}{ Diver Species } \\
\hline Avg. Open Water depth $(\mathrm{cm})$ & 0.02 & 0.01 & 0.03 \\
\hline Vegetation Edge density $(\mathrm{km} / \mathrm{ha})$ & 4.02 & 1.97 & 0.04 \\
\hline Proportion shallow-marsh vegetation & 0.71 & 1.61 & 0.66 \\
\hline Proportion deep-marsh vegetation & -1.07 & 1.17 & 0.36 \\
\hline Fish per trap hour & 0.01 & 0.02 & 0.75 \\
\hline Invertebrates sticky trap & -0.01 & 0.02 & 0.77 \\
\hline Invertebrates activity trap & 0.06 & 0.05 & 0.24 \\
\hline
\end{tabular}

The water depth preferences shown by waterfowl in this study are consistent with other studies (White and James 1978; Savard et al. 1994; Murkin et al. 1997). These preferences are likely a result of food accessibility and nest site availability. Dabbler waterfowl are limited to using shallower water for feeding due to their morphology and feeding tactics (Poysa 1983a). The shallower water in the drawdown wetlands presumably provided dabbler species access to submerged aquatic vegetation and invertebrates on and among the vegetation. The deeper water of the high-water wetlands was likely preferred by diver waterfowl as it provided a greater amount of mobility during feeding and opportunities to escape from threats (Murkin et al. 1997). Deeper water also likely provided diver species with more potential over-water nesting sites compared to the drawdown wetlands. Furthermore, the drawdown wetlands may have been avoided by divers due to the growth of dense submerged aquatic vegetation close to the surface of the water, which may impede the mobility of diving ducks and their broods (Poysa 1983b; Monda and Ratti 1988).

The preference for deeper water by American Coots and Pied-billed Grebes was anticipated as these species require deep water for foraging and escape (Otto 1983; Muller and Storer 1999; Murkin and
Caldwell 2000; Brisbin and Mowbray 2002). However, selection for deeper water by American Bitterns was not expected. We predicted the partial water-level drawdowns would create more areas of emergent vegetation, providing American Bitterns with more cover and structure for overwater movement. We speculate that American Bitterns and Pied-billed Grebes may have been attracted by the abundance of small fish in the high-water wetlands (Muller and Storer 1999). Deeper water in the high-water wetlands may have provided favorable habitat for small fish, including sufficient dissolved oxygen, and prevention of freeze-out during winter (Danylchuk and Tonn 2003). Lower forage fish abundances in wetlands with partial drawdowns may lead to higher abundances of invertebrates, and thus create habitat for insectivorous avian species. Alternatively, high water could be used to promote forage fish abundance and create habitat for piscivorous avian species (Bouffard and Hanson 1997; Danylchuk and Tonn 2003).

Vegetation composition within these boreal wetlands also influenced the densities of a number of species of marsh birds and waterfowl. Soras were likely attracted to shallow-marsh vegetation because Carex seeds provide them with an important food source (Rundle and Sayre 1983; Sayre and Rundle 1984; Johnson and Dinsmore 1986). 
Table 5. Plot-scale effects of resource availability on the presence of marsh birds in the Summerberry Marsh Complex, Manitoba in 2008 and 2009. Results are not available (NA) for invertebrate variables and the American Coot in 2008 as these were not sampled.

\begin{tabular}{|c|c|c|c|c|c|c|}
\hline & \multicolumn{3}{|c|}{2008} & \multicolumn{3}{|c|}{2009} \\
\hline & Estimate & $\mathrm{SE}$ & $\mathrm{p}$ & Estimate & $\mathrm{SE}$ & $\mathrm{p}$ \\
\hline \multicolumn{7}{|l|}{ American Bittern } \\
\hline Avg. Water depth $(\mathrm{cm})$ & 0.05 & 0.02 & 0.03 & 0.06 & 0.03 & 0.04 \\
\hline Vegetation Edge density (km/ha) & 3.64 & 1.96 & 0.07 & 5.04 & 2.30 & 0.04 \\
\hline Proportion shallow-marsh vegetation & -0.02 & 2.50 & 0.99 & -4.01 & 3.63 & 0.28 \\
\hline Proportion deep-marsh vegetation & 0.58 & 1.86 & 0.76 & 1.31 & 2.22 & 0.56 \\
\hline Invertebrates sticky trap & NA & NA & NA & 0.00 & 0.01 & 0.56 \\
\hline Invertebrates activity trap & NA & NA & NA & -0.02 & 0.04 & 0.60 \\
\hline \multicolumn{7}{|l|}{ American Coot } \\
\hline Avg. Water depth (cm) & NA & NA & NA & 0.04 & 0.02 & 0.03 \\
\hline Vegetation Edge density (km/ha) & NA & NA & NA & 5.38 & 2.12 & 0.02 \\
\hline Proportion shallow-marsh vegetation & NA & NA & NA & -4.09 & 2.51 & 0.11 \\
\hline Proportion deep-marsh vegetation & NA & NA & NA & -0.51 & 1.63 & 0.76 \\
\hline Invertebrates sticky trap & NA & NA & NA & 0.01 & 0.01 & 0.11 \\
\hline Invertebrates activity trap & NA & NA & NA & -0.01 & 0.02 & 0.60 \\
\hline \multicolumn{7}{|l|}{ Pied-billed Grebe } \\
\hline Avg. Water depth $(\mathrm{cm})$ & 0.08 & 0.03 & 0.01 & 0.09 & 0.03 & 0.00 \\
\hline Vegetation Edge density (km/ha) & 6.76 & 3.56 & 0.07 & 6.63 & 2.37 & 0.01 \\
\hline Proportion shallow-marsh vegetation & -4.01 & 2.76 & 0.16 & -3.92 & 2.48 & 0.12 \\
\hline Proportion deep-marsh vegetation & 2.01 & 2.10 & 0.35 & 0.51 & 1.62 & 0.76 \\
\hline Invertebrates sticky trap & NA & NA & NA & 0.00 & 0.01 & 0.70 \\
\hline Invertebrates activity trap & NA & NA & NA & 0.01 & 0.020 & .58 \\
\hline \multicolumn{7}{|l|}{ Sora } \\
\hline Avg. Water depth (cm) & 0.02 & 0.03 & 0.50 & -0.03 & 0.02 & 0.13 \\
\hline Vegetation Edge density $(\mathrm{km} / \mathrm{ha})$ & 2.75 & 3.47 & 0.44 & -0.72 & 2.22 & 0.75 \\
\hline Proportion shallow-marsh vegetation & -3.18 & 3.52 & 0.37 & 3.94 & 3.82 & 0.31 \\
\hline Proportion deep-marsh vegetation & -0.65 & 2.93 & 0.83 & -1.69 & 2.42 & 0.49 \\
\hline Invertebrates sticky trap & NA & NA & NA & 0.00 & 0.01 & 0.98 \\
\hline Invertebrates activity trap & NA & NA & NA & 0.19 & 0.12 & 0.11 \\
\hline \multicolumn{7}{|l|}{ Virginia Rail } \\
\hline Avg. Water depth $(\mathrm{cm})$ & -0.02 & 0.02 & 0.29 & -0.01 & 0.02 & 0.47 \\
\hline Vegetation Edge density (km/ha) & -2.67 & 1.86 & 0.16 & -0.03 & 1.65 & 0.99 \\
\hline Proportion shallow-marsh vegetation & 2.90 & 2.65 & 0.28 & 2.20 & 2.16 & 0.32 \\
\hline Proportion deep-marsh vegetation & 0.65 & 1.86 & 0.73 & -3.46 & 1.80 & 0.06 \\
\hline Invertebrates sticky trap & NA & NA & NA & 0.00 & 0.01 & 0.89 \\
\hline Invertebrates activity trap & NA & NA & NA & 0.11 & 0.06 & 0.08 \\
\hline
\end{tabular}

Our observation that Soras and Virginia Rails were not affected by vegetation interspersion is in contrast to Conway (1995), who suggested that Virginia Rails may use interspersion as a cue to select wetlands with high relative abundances of invertebrates. However, vegetation interspersion increased Pied-billed Grebe density and presence, perhaps because it increased availability of nesting sites (Muller and Storer 1999; Rehm and Baldassarre 2007).

Water levels are known to be important drivers of the vegetation community in prairie wetlands (Robel 1961; Anderson 1978; Seabloom et al. 1998; van der Valk 2000). However, in the SMC, our water-level man- agement treatments did not influence the spatial distribution or quantities of emergent vegetation (Baschuk 2010; Ervin 2011). Clearly, effects of water-level drawdowns vary with region and ecosystem, and their effects cannot be assumed without local assessments.

Due to the high avian biodiversity of wetlands in the Saskatchewan River Delta, management of boreal wetlands should be focused on providing a diverse range of water depths. Where possible, water-level management should take place on a wetland-complex scale rather than basin scale; maintaining a variety of water levels in a wetland complex should provide a mosaic of deep and shallow areas to provide habitat for a diversity of species. 


\section{ACKNOWLEDGMENTS}

Project funding was provided by Manitoba Hydro, Ducks Unlimited Canada, Manitoba Conservation, Natural Sciences and Engineering Research Council of Canada and the Kelsey Conservation District. We thank S. Sealy, L. Armstrong and B. Tedford for their help. We are indebted to the staff of Ducks Unlimited Canada in The Pas, including S. Greer, R. Reader, D. Clayton, C. Smith and D. White. Thank you to M. Ervin and assistants H. Brown, Q. Constant and J. Knockaert. Several people from Manitoba Conservation, including G. Ball, D. Cross and C. Hurst provided equipment and allowed us to use their camp and bunkhouse.

\section{Literature Cited}

Anderson, M. G. 1978. Distribution and production of sago pondweed (Potamogeton pectinatus L.) on a northern prairie marsh. Ecology 59: 154-160.

Baker, M. C. 1979. Morphological correlates of habitat selection in a community of shorebirds (Charadriiformes). Oikos 33: 121-126.

Baschuk, M. S. 2010. Effects of water-level management on the abundance and habitat use of waterfowl and marsh birds in the Saskatchewan River Delta, Manitoba, Canada. Unpublished M.Sc. Thesis, University of Manitoba. Winnipeg, Manitoba.

Beamish, R. J. 1973. Design of a trapnet with interchangeable parts for the capture of large and small fishes from varying depths. Journal of Fisheries Research Board of Canada 30: 587-590.

Bolduc, F. and A. D. Afton. 2008. Monitoring waterbird abundance in wetlands: The importance of controlling results for variation in water depth. Ecological Modelling 216: 402-408.

Bouffard, S. H. and M. A. Hanson. 1997. Fish in waterfowl marshes: Waterfowl managers' perspective. Wildlife Society Bulletin 25: 146-157.

Brisbin, I. L., Jr. and T. B. Mowbray. 2002. American Coot (Fulica americana). The Birds of North America Online (A. Poole, Ed.). Ithaca: Cornell Lab of Ornithology; Retrieved from the Birds of North America Online. http://bna.birds.cornell.edu/ bna/species/697a. Accessed September 2009.

Conway, C. J. 1995. Virginia Rail (Rallus limicola). The Birds of North America Online (A. Poole, Ed.). Ithaca: Cornell Lab of Ornithology; Retrieved from the Birds of North America Online. http://bna.birds. cornell.edu/bna/species/173. Accessed September 2009.

Conway, C. J. 2005. Standardized North American marsh bird monitoring protocols. Wildlife Research Report \#2005-04. U.S. Geological Survey, Arizona Cooperative Fish and Wildlife Research Unit, Tucson, Arizona.

Conway, C. J., W. R. Eddleman and S. H. Anderson. 1994. Nesting success and survival of Virginia Rails and Soras. Wilson Bulletin 103: 466-473.

Cox, R. R., Jr. M. A. Hanson, C. C. Roy, N. H. Euliss, Jr., D. H. Johnson and M. G. Butler. 1998. Mallard duckling growth and survival in relation to aquatic invertebrates. Journal of Wildlife Management 62: 124-133.

Danylchuk, A. J. and W. M. Tonn. 2003. Natural disturbances and fish: local and regional influences on winterkill of Fathead Minnows in boreal lakes. Transactions of the American Fisheries Society 132: 289-298.

Eddleman, W. R., F. L. Knopf, B. Meanley, F. A. Reid and R. Zembal. 1988. Conservation of North American rallids. Wilson Bulletin 100: 458-475.

Ervin, M. 2011. Population characteristics and habitat selection of Muskrats (Ondatra zibethicus) in response to water level management at the Summerberry Marsh Complex, The Pas, Manitoba, Canada. Unpublished M.Sc. Thesis, Iowa State University. Ames, Iowa.

Hines, J. E. 2000. DOBSERV-A double-observer approach for estimating detection probability and abundance from avian point counts, USGS-PWRC. www.mbr pwrc.usgs.gov/software.html\#a. Accessed September 2008.

Horak, G. J. 1970. A comparative study of the foods of the Sora and Virginia Rail. Wilson Bulletin 82: 206213.

Hornung, J. P. and A. L. Foote. 2006. Aquatic invertebrate responses to fish presence and vegetation complexity in western boreal wetlands, with implications for waterbird productivity. Wetlands 26: 1-12.

Johnson, R. R. and J. J. Dinsmore. 1986. Habitat use by breeding Virginia Rails and Soras. Journal of Wildlife Management 50: 397-392.

King, R. S. and D. A. Wrubleski. 1998. Spatial and diel availability of flying insects as potential duckling food in prairie wetlands. Wetlands 18: 100-114.

Krull, J. N. 1970. Aquatic plant-macroinvertebrate associations and waterfowl. Journal of Wildlife Management 34: 707-718.

Longcore, J. R., D. G. McAuley, G. W. Pendelton, C. Reid-Bennatti, T. M. Mingo and K. L. Stromborg. 2006. Macroinvertebrate abundance, water chemistry, and wetland characteristics affect use of wetlands by avian species in Maine. Hydrobiologia 567: 143-167.

Lowther, P., A. F. Poole, J. P. Gibbs, S. Melvin and F. A. Reid. 2009. American Bittern (Botaurus lentiginosus). In The Birds of North America Online (A. Poole, Ed.). Ithaca: Cornell Lab of Ornithology. Retrieved from the Birds of North America Online. http:// bna.birds.cornell.edu/bna/species/018. Accessed September 2009.

Monda, M. J. and J. T. Ratti. 1988. Niche overlap and habitat use by sympatric ducks broods in Eastern Washington. Journal of Wildlife Management 52: 95-103.

Morozova, G. S. and N. D. Smith. 2003. Organic matter deposition in the Saskatchewan River floodplain (Cumberland Marshes, Canada): Effects of progradational avulsions. Sedimentary Geology 157: 15-29.

Muller, M. J. and R. W. Storer. 1999. Pied-billed Grebe (Podilymbus podiceps). In The Birds of North America Online (A. Poole, Ed.). Ithaca: Cornell Lab of Orni- 
thology. Retrieved from the Birds of North America Online. http://bna.birds.cornell.edu/bna/species/410. Accessed September 2009.

Murkin, H. R. and J. A. Kadlec. 1986. Relationships between macroinvertebrates densities and waterfowl in a northern prairie marsh. Journal of Wildlife Management 50: 212-217.

Murkin, H. R. and P. J. Caldwell. 2000. Avian use of prairie wetlands. Pages 249-286 in Prairie Wetland Ecology: The Contribution of the Marsh Ecology Research Program (H. R. Murkin, A. G. van der Valk and W. R. Clark, Eds.). Iowa State University Press, Ames, Iowa.

Murkin, H. R., E. J. Murkin and J. P. Ball. 1997. Avian habitat selection and prairie wetland dynamics: a 10-year experiment. Ecological Applications 7: 1144-1159.

Natural Resources Canada. 2009. The atlas of Canada. http://atlas.nrcan.gc.ca/site/english/learningresources/theme_modules/wetlands/index.html. Accessed September 2009.

Nichols, J. D., J. E. Hines, J. R. Sauer, F. W. Fallon, J. E. Fallon and P. J. Heglund. 2000. A double-observer approach to estimating detection probability and abundance from point counts. Auk 117: 393-408.

Otto, J. E. 1983. Breeding ecology of the Pied-billed Grebe (Podilymbus podiceps) on Rush Lake, Winnebago County, Wisconsin. Unpublished M.Sc. Thesis, University of Wisconsin, Oshkosh, Wisconsin.

Partners FOR the Saskatchewan River Basin. 2009. The state of the Saskatchewan River Basin. Partners FOR the Saskatchewan River Basin Report. www.saskriverbasin.ca/page.php?page_id=70\&PHPSESSID=vp 48ugdtta71gng4mkn166b296. Accessed May 2010.

Poysa, H. 1983a. Morphology-mediated niche organization in a guild of dabbling ducks. Ornis Scandinavica 14: 317-326.

Poysa, H. 1983b. Resource utilization pattern and guild structure in a waterfowl community. Oikos 40: 295-307.

Prowse, T. D. and F. M. Conly. 2000. Multiple-hydrologic stressors of a northern delta ecosystem. Journal of Aquatic Ecosystem Stress and Recovery 8: 17-26.

Rehm, E. M. and G. A. Baldassarre. 2007. The influence of interspersion on marsh bird abundance in New York. Wilson Journal of Ornithology 119: 648-654.

Robel, R. J. 1961. Water depth and turbidity in relation to growth of Sago Pondweed. Journal of Wildlife Management 25: 436-438.
Riley, T. Z. and T. A. Bookhout. 1990. Response of aquatic macroinvertebrates to early-spring drawdown in Nodding Smartweed marshes. Wetlands 10: 173-185.

Rundle, D. W. and M. W. Sayre. 1983. Feeding ecology of migrating Soras in Southeastern Missouri. Journal of Wildlife Management 47: 1153-1159.

Sargent, J. C. and D. L. Galat. 2002. Fish mortality and physiochemistry in a managed floodplain wetland. Wetlands Ecology and Management 10: 115-121.

Sayre, M. W. and D. W. Rundle. 1984. Comparison of habitat use by migrating Soras and Virginia Rails. Journal of Wildlife Management 48: 599-605.

Savard, J-P. L., S. W. Boyd and J. G. E. Smith. 1994. Waterfowl-wetland relationships in the Aspen Parkland of British Columbia: Comparison of analytical methods. Hydrobiologia 279/280: 309-325.

Seabloom, E. W., A. G. van der Valk and K. A. Moloney. 1998. The role of water depth and soil temperature in determining initial composition of prairie wetland coenoclines. Plant Ecology 138: 203-216.

Timmermans, S. T. A., S. S. Badzinski and J. W. Ingram. 2008. Associations between breeding marsh bird abundances and great lakes hydrology. Journal of Great Lakes Research 34: 351-364.

Timoney, K. 2002. A dying delta? A case study of a wetland paradigm. Wetlands 22: 282-300.

Timoney, K. 2008. Factors influencing wetland plant communities during a flood-drawdown cycle in the Peace-Athabasca Delta, northern Alberta, Canada. Wetlands 28: 450-46.

United States Fish and Wildlife Service Migratory Bird Data Center. 2009. Waterfowl breeding population and habitat survey. http://migbirdapps.fws.gov/. Accessed September 2009.

van der Valk, A. G. 2000. Vegetation dynamics and models. Pages 125-161 in Prairie Wetland Ecology: The Contribution of the Marsh Ecology Research Program (H. R. Murkin, A. G. van der Valk and W. R. Clark, Eds.). Iowa State University Press, Ames, Iowa.

White, D. H. and D. James. 1978. Differential use of freshwater environments by wintering of coastal Texas. Wilson Bulletin 90: 99-111.

Zimmer, K. D., M. A. Hanson and M .G. Butler. 2000. Factors influencing invertebrate communities in prairie wetlands: a multivariate approach. Canadian Journal of Fisheries and Aquatic Sciences 57: 76-85. 


\section{Appendix}

Appendix 1. Number of fish caught per trap hour in 2008 and 2009 in the Summerberry Marsh Complex, Manitoba, Canada.

\begin{tabular}{|c|c|c|c|c|c|c|c|c|}
\hline & \multicolumn{2}{|c|}{ Brook Stickleback } & \multicolumn{2}{|c|}{ Central Mudminnow } & \multicolumn{2}{|c|}{ Fathead Minnow } & \multicolumn{2}{|c|}{ Total } \\
\hline & 2008 & 2009 & 2008 & 2009 & 2008 & 2009 & 2008 & 2009 \\
\hline Drawdown & 2.27 & 1.46 & 0.00 & 0.10 & 0.02 & 0.00 & 2.29 & 1.56 \\
\hline High Water & 14.88 & 14.58 & 0.63 & 1.17 & 12.15 & 13.75 & 27.66 & 29.49 \\
\hline
\end{tabular}

Appendix 2. Average number of invertebrates caught per trap in the drawdown and high water wetlands during the first two surveys rounds in 2009 in the Summerberry Marsh Complex, Manitoba, Canada. Shaded rows indicate drawdown wetlands.

\begin{tabular}{lcc}
\hline Wetland & Activity Trap & Sticky Trap \\
\hline 14R & 4.30 & 56.00 \\
$36 \mathrm{C}$ & 3.25 & 49.00 \\
$35 \mathrm{HI}$ & 6.84 & 49.41 \\
$21 \mathrm{C}$ & 16.88 & 66.79 \\
34HI & 4.33 & 47.04 \\
32C & 1.44 & 53.04 \\
\hline
\end{tabular}

